\title{
Widya Pustaka: A Tool for Teaching Preparation
}

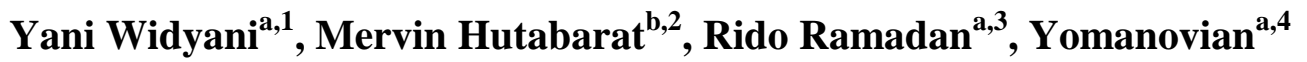 \\ ${ }^{a}$ School of Electrical Engineering and Informatics ITB, Jl. Ganesha 10, Bandung 40132, Indonesia \\ 1'yani@informatika.org, ${ }^{2}$ mhutabar@gmail.com, ${ }^{3}$ rido.ramadan@gmail.com, ${ }^{4}$ yomanovian@gmail.com
}

\begin{abstract}
This paper describes the proposed software product, an application tool for teaching preparation, called Widya Pustaka. It includes planning the teaching activity and composing the teaching materials into a package ready to deliver to the students in class. The lesson plan will be built using a standardized template. It includes the topic covered, the objectives, the teaching scenarios, and the problem set. According to the newest curriculum, the lesson plan should cover several subjects, such as Math, Science, etc., that form an integrated scenario. The teaching scenarios will be incorporated with related teaching materials to form a package ready to deliver to the students in class. Widya Pustaka will be used by a teacher, to help preparing one session of teaching activity. The tool should be designed as simple as possible to increase the ease of use. The user will be guided step by step to build the lesson plan and the teaching-ware package. In the past three years, an elementary teacher community in West Java has been developed, as a part of the result of our research in digital learning. Several teachers from elementary school in Bandung, Subang, and Cianjur are involved in this community. This research intended to improve the quality of learning activities, especially at the elementary level. ICT-based learning activities were conducted such as ICT-based lesson study. Widya Pustaka is one of several ICT-based tools that will support all community member activities defined in several program. This tool will be validated by this community.
\end{abstract}

Index Terms - software, tool, teaching, preparation

\section{Introduction}

Changes in Indonesia education and curriculum have demanded a new teaching approach for elementary school teachers. One of the main focuses of the curriculum changes was the adoption of information, communication, and technology (ICT) during the teaching process.

In ICT Research Center of ITB, we have been into the matter of digital learning application and research since 2009. The research involves external stakeholders from UPI (Universitas Pendidikan Indonesia - Indonesia University of Education) and several elementary school teachers from Bandung, Subang, and Cianjur. UPI researchers are responsible of the definition of digital learning process, ITB researchers are responsible for development of the digital learning technology derived from its definition, and the elementary school teachers are responsible for the execution and evaluation of the implementation of digital learning technology. This joint-research has several products ranging from ICT-based lesson study through teaching process using virtual class.

Our research in this paper focuses on ICT-based lesson study. The goal to adopt ICT in lesson study was to provide method to eliminate the needs of traditional lesson study in which teachers must gathered in one particular place. Utilizing ICT in lesson study enables distant lesson study and minimizes the needs to gather people. The only thing remains is the time to conduct the distant lesson study.

In this paper, we proposed several tools to support and enhance the application of distant lesson study. The tools we developed is called Widya Pustaka, consists of two main parts: teaching plan application and teaching material application.

\section{Related Work}

\section{A. The Lesson Study}

Lesson study is a model of teacher coaching through study of collaborative and continuous learning, based on colleagues and mutual learning principles to encourage development of learning community [1]. Lesson study is not a learning method or strategy. A new approach of learning can be identified based on the real situation, condition, and problem found.

The objective of conducting lesson study is to improve the quality of learning. Lesson study consists of three phases: (1) plan, (2) do, and (3) see, as shown in Figure 1. At first phase, teachers learn to develop a lesson plan. At the second phase, a selected teacher (the model) must conduct an open lesson, which is one session of teaching in class attended by other teachers as observers. At the third phase, the lesson study tutor conducts a reflection with all of the observers and the (teacher) model, which is a discussion about the teaching session.

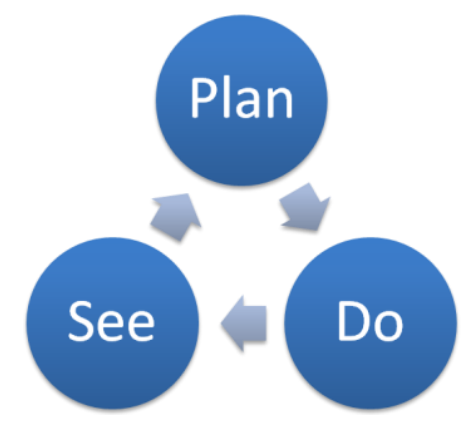

Fig. 1 Three Phases of Lesson Study

Most of activities in the first phase are in a form of discussion. Teachers discuss which learning topic will be prepared. Teachers develop lesson plan for the selected topic. The tutor gives feedback to the participants about the open lesson to improve the next open lesson. These three phases should be conducted several times to gain more advantages of the lesson study. 


\section{B. The Lesson Plan}

The lesson plan must be developed before the teaching class is conducted. Lesson plan is a detailed description of an instructor's course of instruction for an individual lesson intended to help learners achieve a particular learning objective [2]. The lesson plan is developed for each teaching session. Structure of the lesson plan is shown in Figure 2.

\begin{tabular}{|l|}
\hline Grade \\
Semester \\
Standard competence \\
Basic competences \\
Time allocated \\
Authors \\
Institution of the authors \\
Learning indicators \\
Learning objectives \\
Teaching materials (books/references) \\
Learning methods (practical/theory) \\
Learning scenario \\
1. Opening \\
$2 . \quad$ Core activities \\
$\quad$ a. Elaboration \\
$\quad$ b. Exploration \\
c. Confirmation \\
Closing \\
Tools and resources \\
Assessment \\
\hline
\end{tabular}

Fig. 2 The Content of The Lesson Plan

\section{The Overall Architecture}

Widya Pustaka is a web application. The architecture chosen is a layered application. The presentation layer is responsible for the web rendering and displaying the information to user. Business layer is responsible for logic, calculation, and data modification. Data access layer is responsible for database store/retrieve and propagate data modification from business layer into database operation that will modify the respective tables.

Besides, Widya Pustaka can be observed as a thin web client application. Several advantages of thin web client architecture are [3]: (1) the ability to deliver the system to as many types of user systems as possible, (2) requiring only minimal capabilities on the client, and (3) the ability to operate in low-bandwidth environments, etc.

As shown in Figure 3, Widya Pustaka consists of two main features: (1) lesson plan editor, and (2) teaching material editor. These two features both rely on a shared multimedia repository. As for the teaching material feature, it has an export API to provide services to external system.

\section{Widya Pustaka Functionalities}

According to the overall architecture above, Widya Pustaka consist of two main components: (1) lesson plan editor, and (2) teaching material editor. The core functionalities are shown in Table 1.

To log into the system, teachers must pass through the authentication system. After authentication, system will display the dashboard as shown Figure 4. The list of most recent 5 lesson plans and teaching materials will be shown. To raise teacher motivation, a social media aspect will be implemented. A teacher can view activities of other teachers. A teacher can view and give a comment on a specific lesson plan or teaching material. Then, a community of teachers can share experience of developing lesson plan and teaching material.

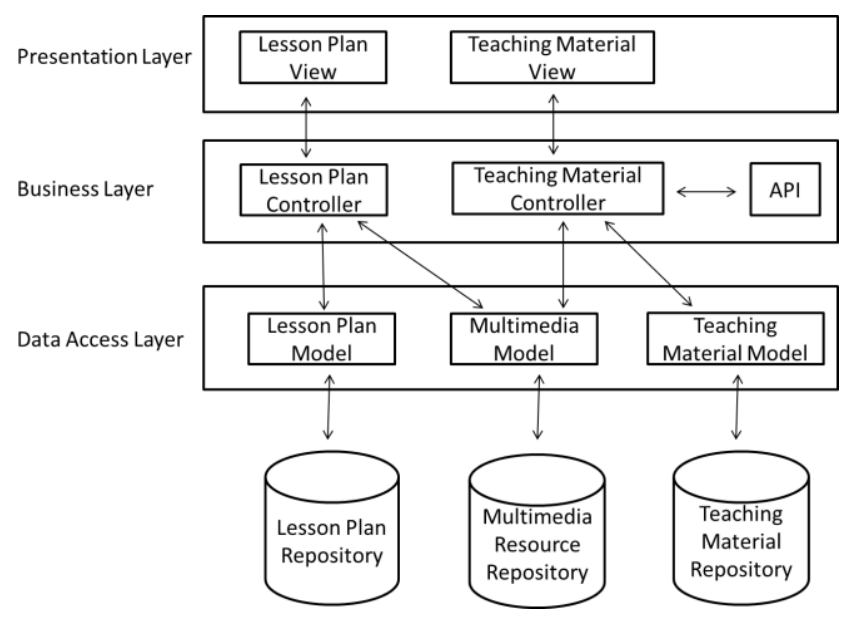

Fig. 3 The Overall Architecture of Widya Pustaka

TABLE 1 Widya Pustaka Functionalities

\begin{tabular}{|c|l|}
\hline ID & \multicolumn{1}{c|}{ Functionality } \\
\hline WP-F-001 & Login and open the dashboard \\
\hline WP-F-002 & View the list of lesson plan \\
\hline WP-F-003 & Create a new lesson plan \\
\hline WP-F-004 & View the list of teaching materials \\
\hline WP-F-005 & Create a new teaching material package \\
\hline WP-F-006 & Update the lesson plan \\
\hline WP-F-007 & Update the teaching materials \\
\hline WP-F-008 & Upload the teaching material's files \\
\hline WP-F-009 & $\begin{array}{l}\text { Submit the teaching material package to the } \\
\text { Digital Store }\end{array}$ \\
\hline
\end{tabular}

A teacher can develop a lesson plan in the easiest way. Step by step guidance will be given. A teacher can reuse a public domain lesson plan which provided by the government to create his own lesson plan. The lesson plan will be stored in the repository.

A teacher can develop a package of teaching material according to an existing lesson plan. The scenario can be refined and the corresponding teaching material file can be attached to each step in the scenario. This package will be stored in the repository and ready to deliver in class.

The lesson plan or the teaching material can be developed by several authors. Each author has permission to edit his lesson plans or teaching materials. A group role is defined to permit each member to view all of the lesson plans and teaching materials created by other member of the group. It also permits each member to put a comment. 


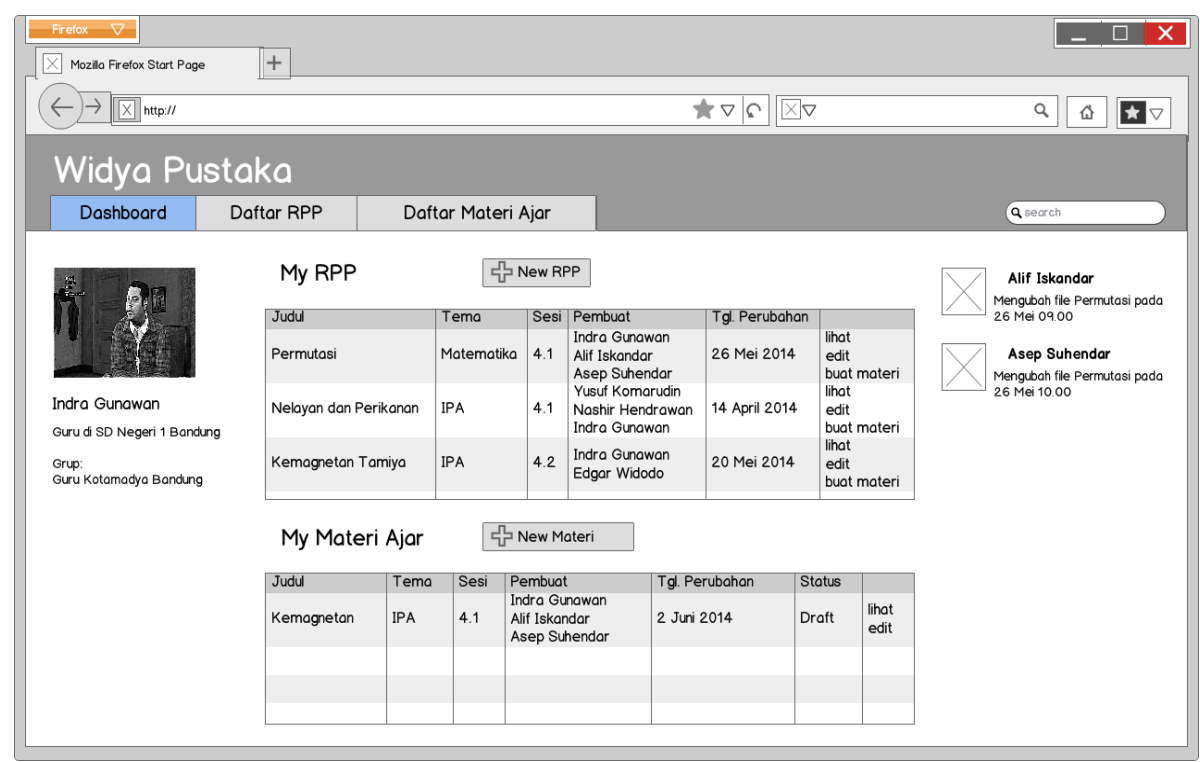

Fig. 4 Widya Pustaka Dashboard

\section{Data Model}

The data model used in Widya Pustaka represents how lesson learned, teaching materials, multimedia resources, and authors' user access related to each other. For a simple representation of the data, we choose Object-Relational database, where we treat the data in Widya Pustaka web application as object like in object-oriented paradigm but the store/retrieval mechanism using relational database. The data model is shown in Figure 5.

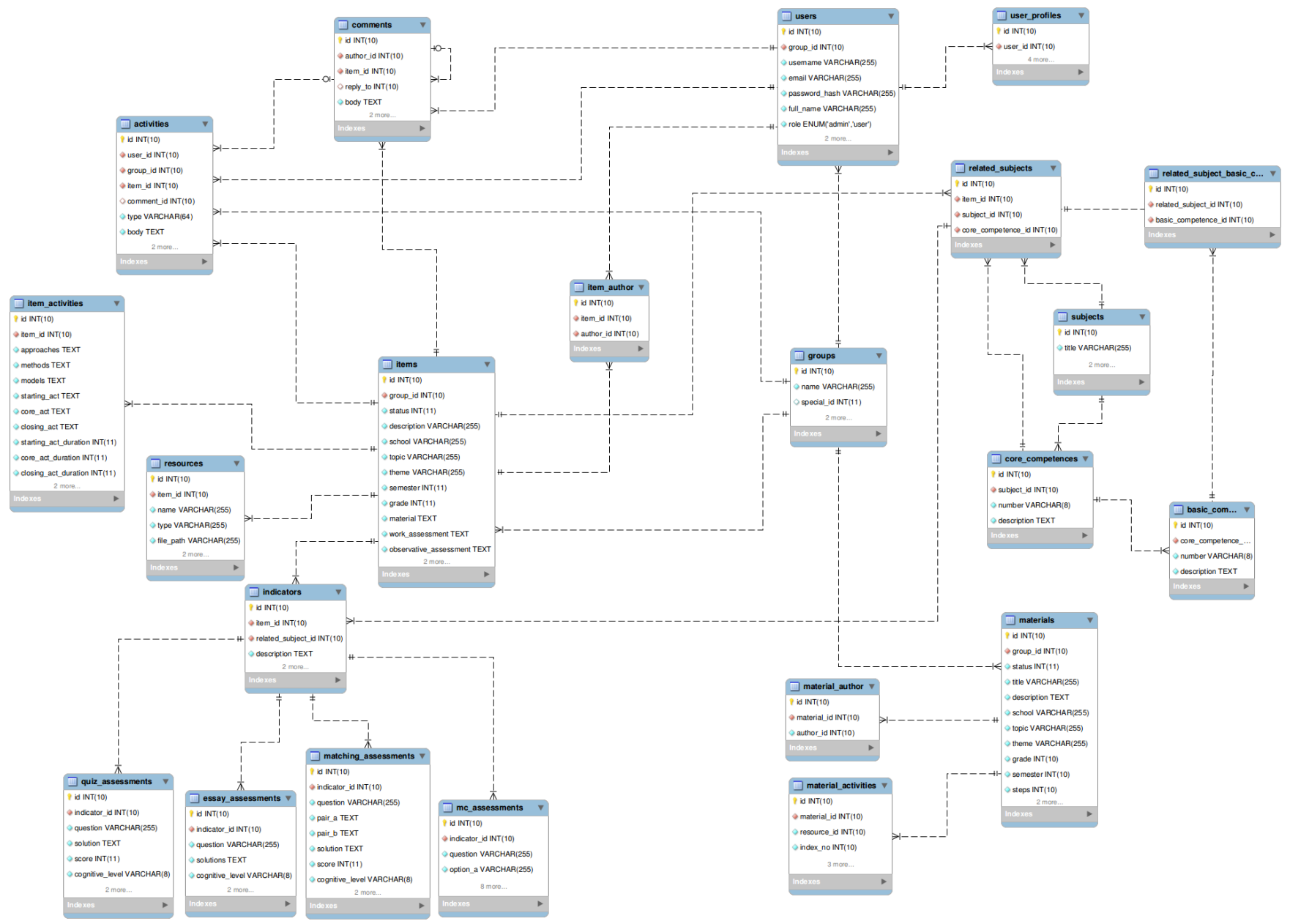

Fig. 5 The Data Model 


\section{Implementation of Widya Pustaka}

Widya Pustaka web application is developed using Laravel Framework, a PHP 5.5 framework [4]. Laravel by default has ORM database component: Eloquent ORM [5] which applied Active Record pattern [6]. Active Record design pattern treat relational table in database management system (DBMS) as a live object, which has lifetime and scope comply with the object-oriented paradigm. Every object property modification by the application will be translated into respective database operation. Therefore developer does not need to concern about the database querying and operation anymore. They only need to know how to modify object property and Eloquent ORM will then do the rest.

To improve the extensibility of Widya Pustaka, RESTful API [7] for teaching material data retrieval is also developed. The data is provided in Javascript Object Notation (JSON) format [7], which is one of the best object representations as text file. The JSON API will ease up the development of software which utilizes our Widya Pustaka data, whether in a form of desktop application, web application, or mobile application.

\section{Future Work}

Widya Pustaka is one of our continuous researches in ITB ICT Research Center. The lesson plans and the teaching materials data will be utilized by teacher companion app. The companion app currently under development as Android application that will be deployed to our partner's device: SpeedUp tablet by PT. MLW. For the next part of this research, collaboration with PT. MLW will be managed to host the cloud service which house all of all lesson plan and teaching material data.

\section{Acknowledgment}

We would like to acknowledge DIKTI and ITB for the research funding as part of the RAPID Program - DIKTI 2014.

\section{References}

[1] Liliasari, "Lesson study untuk meningkatkan kemampuan Profesional guru SD", 2010

[2] K. Barroso and S. Pon, "Effective lesson planning, a facilitator's guide," California Adult Literacy Professional Development Project. American Institutes for Research, Sacramento, CA, 2005

[3] J. Conallen, Building web applications with UML, Second Edition, Addison-Wesley Professional, 2003.

[4] Laravel. (2014). Laravel - The PHP Framework for Web Artisants. [Online]. Available: http://laravel.com.

[5] Laravel. (2014). Laravel Documentation. [Online]. Available: $\mathrm{http} / / /$ laravel.com/docs/4.2/eloquent.

[6] M. Fowler, Patterns of enterprise application architecture, AddisonWesley, 2003.

[7] R.T. Fielding and R.N. Taylor, "Principled design of the modern web architecture", ACM Transactions on Internet Technology, vol. 2, no. 2, pp. $115-150,2002$. 